\title{
Narrowing the Gap between the Anion Gap and the Strong Ion Gap
}

\author{
Berend $\mathrm{K}^{1 *}$ and Lundquist $\mathrm{A} \mathrm{L}^{2}$ \\ ${ }^{1}$ Department of Medicine, St. Elisabeth Hospital, Netherlands \\ ${ }^{2}$ Division of Nephrology, Massachusetts General Hospital, United States
}

Submission: February 11, 2017; Published: June 01, 2017

*Corresponding author: Kenrick Berend, Department of Medicine, St. Elisabeth Hospital, p/a: St. Michielsweg 13, Curaçao, Netherlands Antilles, Email: kenber2@me.com

\begin{abstract}
Background: Despite its importance in understanding acid-base pathophysiology, many physicians do not comprehend the concept of the strong anion gap (SIG), the core of the Stewart acid-base approach. The quantitative difference between the anion gap and the strong ion gap is not established. This paper will give insight into this difference over a variety of conditions Methods. The empiric difference between the SIG and the albumin-corrected anion gap (AGc) was calculated at a wide range of albumin, phosphorus and pH levels.

Results: At an albumin level of 1-3 g/dl and $\mathrm{pH}$ from 6.9-7.3, the contribution difference of albumin between the AG and the SIG will be maximally -0.97 to $0.51 \mathrm{mEq} / \mathrm{L}$. In metabolic alkalosis and hypoalbuminaemia, the $\mathrm{AG}_{\mathrm{c}}$ differs less than $2 \mathrm{mEq} / \mathrm{L}$ from the SIG. The calculated contribution of phosphorus is higher in the SIG with phosphorus levels $>2 \mathrm{mmol} / \mathrm{L}$ and can be accounted for in the anion gap with the conversion factor 1.76* [phosphorus, in mmol/L].

Conclusion: The SIG and the $\mathrm{AG}_{\mathrm{c}}$ are nearly identical across a wide range of values, particularly when albumin and phosphorus levels are low. The anion gap will be more precise and incorporate the major components of the SIG using the equation: $\left[\mathrm{Na}^{+}\right]-[\mathrm{Cl}-]-\left[\mathrm{HCO}_{3}-\right]-2.5^{*}[\mathrm{albumin}$ in $\mathrm{g} / \mathrm{dL}$ ] $-1.76^{*}$ [phosphorus, in mmol/L], with an arbitrarily set reference range of $1 \pm 5 \mathrm{mEq} / \mathrm{L}$

Keywords: Acid-base; Anion gap; Strong anion gap; Stewart

Abbreviations: $\mathrm{AG}_{\mathrm{c}}$ : Corrected Anion Gap; $\mathrm{Alb}_{\mathrm{st}}$ : Albumin Measured By The Stewart Formula; $\mathrm{P}_{\mathrm{st}}$ : Phosphate Measured with the Stewart Formula; $\mathrm{AG}_{\mathrm{a}+\mathrm{p}}$ : AG Corrected for Albumin and Phosphorus
\end{abstract}

\section{Introduction}

For more than 40 years clinicians have used the anion gap (AG) as a major tool to evaluate acid-base disorders. A positive value of the $A G$ suggests a possible organic acidosis due to endogenous acids or the intake of exogenous acids [1]. Although the concept of the AG was described in 1936 by James Gamble [2], it did not gain widespread recognition by physicians until the 1970s after the introduction of auto analyzers and the rapid availability of multiple analytes. According to Gamble, electrical neutrality in solution demands that the sum of the cations is equal to the sum of the anions, also represented in a Gamblegram (Figure 1). Sodium, chloride, bicarbonate and albumin are quantitatively the major ions in the extracellular fluid compartment and are therefore used to calculate the anion gap. A true "ion gap" does not exist in vivo which makes the anion gap a fundamental tool to evaluate acid-base disorders [1]. In 1978 Peter Stewart challenged the traditional bicarbonatebased approach, by reasoning that his approach offered both a mechanistic explanation and provided the tool to make a more accurate diagnosis [3]. The core of the Stewart approach is the strong anion gap (SIG): Equation 1.

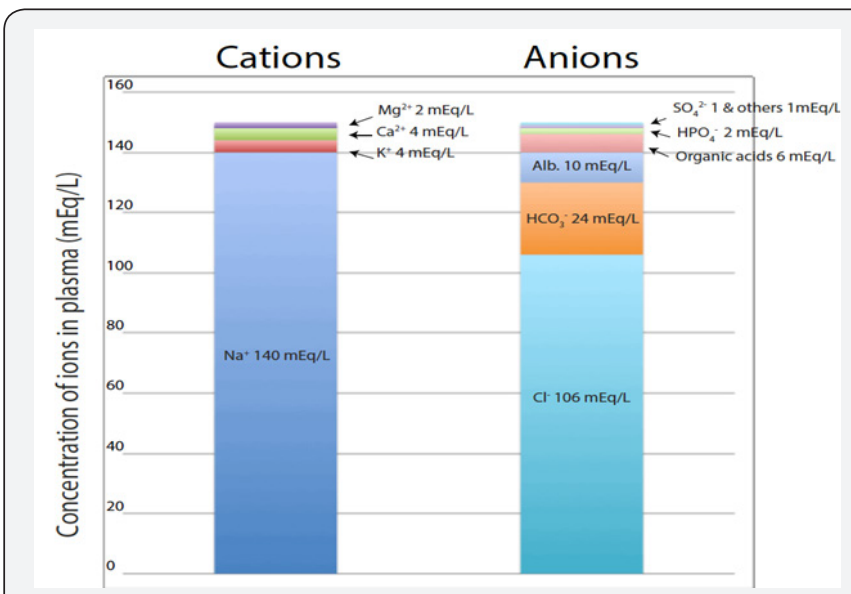

Figure 1: Gamblegram: balance between anions and cations in plasma. 
$\left[\mathrm{Na}^{+}\right]+\left[\mathrm{K}^{+}\right]+\left[\mathrm{Ca}^{2+}\right]+\left[\mathrm{Mg}^{2+}\right]-[\mathrm{Cl}-]-[$ lactate- $]-12.2 \times \mathrm{pCO}_{2} /$ $\left(10^{-\mathrm{pH}}\right)-10 \times[$ albumin $\left.] \times 0.123 \times \mathrm{pH}-0.631\right)-\left[\mathrm{PO}_{4^{-}} \quad\right.$ in $\mathrm{mmol} /$ $\mathrm{L}] \times(0.309 \times \mathrm{pH}-0.469)=+0 \mathrm{mEq} / \mathrm{L}$

This complex formula quantitatively accounts for the contribution of weak acids to the electrical charge equilibrium in plasma [3]. On first glance there is a substantial difference from the $A G$ equation: Equation 2.

\section{$[\mathrm{Na}+]-[\mathrm{Cl}]-\left[\mathrm{HCO}_{3}\right]=+10 \mathrm{mEq} / \mathrm{L}$}

Though the SIG gives a wider-ranging picture of the ion balance than the AG, controversial opinions about its real value remain and several differences are observed between the SIG and the AG:

a. The SIG is popular amongst intensivists, though additional parameters can increase variability and error $[4,5]$. Additionally, small changes in $\mathrm{K}^{+}, \mathrm{Ca}^{2+}$ and $\mathrm{Mg}^{2+}$ are rarely of consequence due to narrow variations in health and disease. Nevertheless, some clinicians include $\mathrm{K}$ in the AG. Likewise, one can include $\mathrm{Ca}$ and $\mathrm{Mg}$ in the AG. The AG may therefore be written like $\left[\mathrm{Na}^{+}\right]+\left[\mathrm{K}^{+}\right]+\left[\mathrm{Ca}^{2+}\right]+\left[\mathrm{Mg}^{2+}\right]-[\mathrm{Cl}$ ]-[$\left[\mathrm{HCO}_{3}^{-}\right]$; the reference value should increase accordingly. These kations are included in SIG (equation 1). When concentrations of these cations are changed substantially one may include them in the AG as well. Therefore, these cations are not relevant for the discussion.

b. Lactate may be included in the SIG, but clinicians will typically know when a high AG or SIG is caused by lactate, because lactate is often tested in severly ill patients with metabolic acidosis.

c. The formula $12.2 \times \mathrm{pCO}_{2} /\left(10^{-\mathrm{pH}}\right)$ is used by blood gas devices to calculate the bicarbonate concentration and may be therefore replaced by it. This leaves us with the following equation which starts to approximate the more familiar anion gap: Equation 3.

$\left[\mathrm{Na}^{+}\right]-\left[\mathrm{Cl}^{-}\right]-\left[\mathrm{HCO}_{3}^{-}\right]-10 \times[$ albumin $] \times(0.123 \times \mathrm{pH}-0.631)-$ $\left[\mathrm{PO}_{4}^{-}\right] \times(0.309 \mathrm{pH}-0.469)=+0 \mathrm{mEq} / \mathrm{L}$.

d. Thus, the "only" real difference between the SIG and the $\mathrm{AG}$ is that albumin and phosphorus are adjusted for changes in $\mathrm{pH}$ in the SIG. The purpose of this study is to determine the significance of this difference across a wide range of conditions.

\section{Methods}

The quantitative difference between the SIG and the $\mathrm{AG}_{\mathrm{c}}$ was calculated at a wide range of albumin (from 1 to $5 \mathrm{~g} / \mathrm{L}$ ), phosphorus (from 0.5to4mmol/L) and $\mathrm{pH}$ levels (from 6.9to7.6) with otherwise standard parameters. For example, with an albumin of $4 \mathrm{~g} / \mathrm{dl}$ and a pH of 6.9 , the albumin effect on the anion gap will be $10 \mathrm{mmol} / \mathrm{L}$ regardless of the $\mathrm{pH}$. The SIG will change using the formula $10 \times[$ albumin] $\times(0.123 \times \mathrm{pH}-0.631)$, by $8.71 \mathrm{mmol} / \mathrm{L}$. Thus, the $\Delta$ AlbSt $-10=8.71-10=-1.29 \mathrm{mmol} / \mathrm{L}$. Similarly, with a phosphorus of $1 \mathrm{mmol} / \mathrm{L}$ and a pH of 6.9 , the $\mathrm{PSt}=[\mathrm{PO} 4-] \times(0.309 \times \mathrm{pH}-0.469)=1.66 \mathrm{mEq} / \mathrm{l}$ difference with the AG.

\section{Results}

At an albumin level of 1-3 g/dl and a pH from 6.9-7.3, the contribution difference of albumin in the AGc and the SIG will be maximally -0.97 to $0.51 \mathrm{mEq} / \mathrm{L}$, suggesting little difference between the two methods (Table 1). In metabolic alkalosis and hypoalbuminaemia, once again the AGc differs less than $2 \mathrm{mEq} / \mathrm{L}$ from the SIG. Incorporation of high values of phosphorus in the SIG on the contrary, is significant and there is a linear relationship of the serum phosphorus and the ionic contribution in the SIG. This effect will therefore be more notable at higher phosphorus levels (Table 1).

Table 1: Calculated difference in albumin and phosphorus concentration via the Steward and Anion Gap methods across a physiologic pH range.

\begin{tabular}{|c|c|c|c|c|c|c|c|c|c|}
\hline & pH & 6.9 & 7 & 7.1 & 7.2 & 7.3 & 7.4 & 7.5 & 7.6 \\
\hline \multicolumn{10}{|c|}{ Albumin $^{\mathrm{a}}$} \\
\hline $1 \mathrm{~g} / \mathrm{dL}$ & & 2.18 & 2.3 & 2.42 & 2.55 & 2.67 & 2.79 & 2.92 & 3.04 \\
\hline$\Delta$ AlbSt -2.5 & & -0.32 & -0.2 & -0.08 & 0.05 & 0.17 & 0.29 & 0.42 & 0.54 \\
\hline $2 \mathrm{~g} / \mathrm{dL}$ & & 4.35 & 4.6 & 4.85 & 5.09 & 5.34 & 5.58 & 5.83 & 6.08 \\
\hline$\Delta$ AlbSt -5 & & -0.65 & -0.4 & -0.15 & 0.09 & 0.34 & 0.58 & 0.83 & 1.08 \\
\hline $3 \mathrm{~g} / \mathrm{dL}$ & & 6.53 & 6.9 & 7.27 & 7.64 & 8.01 & 8.38 & 8.75 & 9.11 \\
\hline$\Delta$ AlbSt -7.5 & & -0.97 & -0.6 & -0.23 & 0.14 & 0.51 & 0.88 & 1.25 & 1.61 \\
\hline $4 \mathrm{~g} / \mathrm{dL}$ & & 8.71 & 9.2 & 9.69 & 10.18 & 10.68 & 11.17 & 11.66 & 12.15 \\
\hline$\Delta$ AlbSt - 10 & & $-1.29^{b}$ & -0.8 & -0.31 & 0.18 & -0.68 & 1.17 & 1.66 & 2.15 \\
\hline $5 \mathrm{~g} / \mathrm{dL}$ & & 10.89 & 11.5 & 12.12 & 12.73 & 13.35 & 13.96 & 14.58 & 15.19 \\
\hline$\Delta$ AlbSt - 12.5 & & -1.61 & -1 & -0.38 & 0.23 & 0.85 & 1.46 & 2.08 & 2.69 \\
\hline \multicolumn{10}{|c|}{ Phosphorus $^{\text {b }}$} \\
\hline
\end{tabular}


Journal of Anesthesia \& Intensive Care Medicine

\begin{tabular}{|c|l|c|c|c|c|c|c|c|c|}
\hline $0.5 \mathrm{mmol} / \mathrm{L}$ & & 0.83 & 0.85 & 0.86 & 0.88 & 0.89 & 0.91 & 0.92 & 0.94 \\
\hline$\Delta \mathrm{PSt}-0.5$ & & 0.33 & 0.35 & 0.36 & 0.38 & 0.39 & 0.41 & 0.42 & 0.44 \\
\hline $1 \mathrm{mmol} / \mathrm{L}$ & & 1.66 & 1.7 & 1.72 & 1.76 & 1.78 & 1.82 & 1.84 & 1.86 \\
\hline$\Delta \mathrm{PSt}-1$ & & $0.66^{\mathrm{b}}$ & 0.7 & 0.72 & 0.76 & 0.78 & 0.82 & 0.84 & 0.86 \\
\hline $2 \mathrm{mmol} / \mathrm{L}$ & & 3.33 & 3.4 & 3.44 & 3.52 & 3.56 & 3.64 & 3.66 & 3.68 \\
\hline$\Delta \mathrm{PSt}-2$ & & 1.33 & 1.4 & 1.44 & 1.52 & 1.56 & 1.64 & 1.66 & 1.68 \\
\hline $3 \mathrm{mmol} / \mathrm{L}$ & & 4.99 & 5.1 & 5.16 & 5.28 & 5.34 & 5.46 & 5.52 & 5.58 \\
\hline$\Delta \mathrm{PSt}-3$ & & 1.99 & 2.1 & 2.16 & 2.28 & 2.34 & 2.46 & 2.52 & 2.58 \\
\hline $4 \mathrm{mmol} / \mathrm{L}$ & & 6.65 & 6.8 & 6.88 & 7.04 & 7.12 & 7.28 & 7.36 & 7.44 \\
\hline$\Delta \mathrm{PSt}-4$ & & 2.65 & 2.8 & 2.88 & 3.04 & 3.12 & 3.28 & 3.36 & 3.44 \\
\hline
\end{tabular}

AlbSt $=$ albumin concentration calculated by the Stewart method: $10 \times$ [albumin] $\times(0.123 \times \mathrm{pH}-0.631)$.

$\mathrm{PSt}=$ phosphorus concentration calculated by the Stewart method: $\left[\mathrm{PO}_{4}-\right.$ in $\left.\mathrm{mmol} / \mathrm{L}\right] \times(0.309 \times \mathrm{pH}-0.469)$.

$\Delta \mathrm{Alb}_{\mathrm{St}}$ - albumin at a certain level calculated by the Stewart method minus the albumin concentration adjusted for the corrected anion gap method $(2.5 \mathrm{~g} / \mathrm{dL}$ for each $\mathrm{g} / \mathrm{dL}$ change). Example: with albumin $=4 \mathrm{~g} / \mathrm{dl}$ at a pH $=6.9$ the albumin effect on the anion gap will be $10 \mathrm{mmol} / \mathrm{L}$ (regardless of the $\mathrm{pH}$ in the anion gap concept). The SIG will change using the formula $10 \times$ [albumin] $\times(0.123 \times \mathrm{pH}-0.631)$, by $8.71 \mathrm{mmol} / \mathrm{L}$. $\Delta \mathrm{Alb}_{\mathrm{St}}-10=8.71-10=-1.29 \mathrm{mmol} / \mathrm{L}$.

$\Delta \mathrm{P}_{\mathrm{St}}$ phosphorus concentration at a certain level calculated by the Stewart method minus the phosphorus. Example: If the phosphorus is 1 $\mathrm{mmol} / \mathrm{L}$ and the $\mathrm{pH}$ is 6.9 , the change in SIG will be $1.66 \mathrm{mmol} / \mathrm{L}$ using the formula: $\left\{\left[\mathrm{PO}_{4}^{-}\right] \times(0.309 \times \mathrm{pH}-0.469)\right\}$. The pH adjusted level

$\otimes \mathrm{PSt}-1=1.66-1=0.66 \mathrm{mmol} / \mathrm{L}$.

aReference range albumin (3.5-5.5 g/dL)

${ }^{\mathrm{b}}$ Reference value phosphorus: $0.97-1.45 \mathrm{mmol} / \mathrm{L}$

\section{Discussion}

Body fluid compartments have varying concentrations of non-volatile weak acids, with albumin and inorganic phosphorus the primary components in plasma [3]. The anion gap is used to evaluate metabolic acidosis and is calculated as follows:

\section{$\left[\mathrm{Na}^{+}\right]-[\mathrm{Cl}]-\left[\mathrm{HCO}_{3}^{-}\right]$}

Because of the narrow extracellular concentration, $\mathrm{K}^{+}$is often omitted from the calculation. To be more precise, one should correct the anion gap for hypoalbuminemia. To appreciate the relevance of this correction one can consider a healthy individual with the following serum values:

$\left[\mathrm{Na}^{+}\right]=140 \mathrm{mEq} / \mathrm{L},[\mathrm{Cl}-]=106 \mathrm{mEq} / \mathrm{L},\left[\mathrm{HCO}_{3}{ }^{2-}\right]=24 \mathrm{mEq} / \mathrm{L}$.

The $A G=10 \mathrm{mEq} / \mathrm{L}$, representing primarily albumin. The correction factor for albumin is 2.3-2.5* [albumin], in $\mathrm{g} / \mathrm{dL}$ [1]. The albumin corrected AG (AGa) equation can therefore be written as: Equation 4.

$\left[\mathrm{Na}^{+}\right]-\left[\mathrm{Cl}^{-}\right]-\left[\mathrm{HCO}_{3}{ }^{2-}\right]-2.5$ [albumin, in $\left.\mathrm{g} / \mathrm{dL}\right]=0+5 \mathrm{mEq} / \mathrm{L}$.

This equation gives a better understanding of the principle that there is no actual "gap" between the positive and negative ions and likewise, the "AG" should be zero in-vivo. However, comparing this formula with the SIG, one will observe that a major difference is the inclusion of phosphorus in the SIG and that albumin and phosphorus are both adjusted for changes in $\mathrm{pH}$. The question is therefore if one should include phosphorus as well in the AG.

\section{Albumin}

Hypoalbuminemia is common in patients with acid-base disorders. With an albumin of 1-3 g/dl, the contribution difference of albumin between the $\mathrm{AG}_{\mathrm{c}}$ and the SIG will be maximally -0.97 to $1.6 \mathrm{mEq} / \mathrm{L}$ regardless of $\mathrm{pH}$ (Table 1 ). Therefore, the $\mathrm{pH}$ correction of albumin used in the SIG formula is irrelevant in the evaluation of metabolic acidosis, as long as the $\mathrm{AG}$ is adjusted for albumin.

\section{Phosphorus}

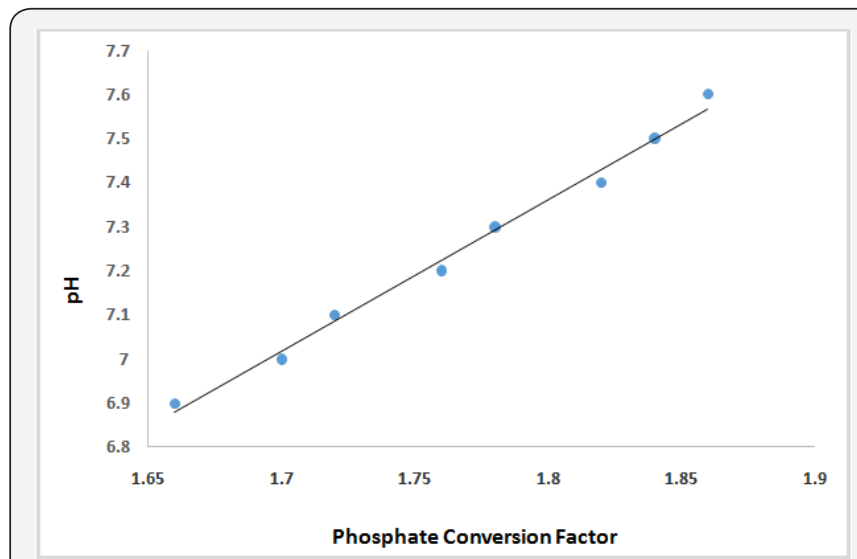

Figure 2: Phosphate conversion factor plotted against a pH range of 6.8 to 7.7 . This relationship can be incorporated into the traditional anion gap using a conversion factor, with the average conversion factor determined to be $1.76{ }^{*}$ [phosphorus].

When phosphorus levels are normal or reduced, there is little contribution $(<2 \mathrm{mmol} / \mathrm{L})$ to the AG (Table 1$)$. If phosphorus levels are elevated, as in renal failure, the ionic contribution, however, becomes more significant. Suppose we have a patient with renal failure and the following plasma electrolytes: $\left[\mathrm{Na}^{+}\right]=140 \mathrm{mEq} / \mathrm{L}, \quad\left[\mathrm{Cl}^{-}\right]=106 \mathrm{mEq} / \mathrm{L}, \quad\left[\mathrm{HCO}_{3}{ }^{2-}\right]=24 \mathrm{mEq} / \mathrm{L}$, albumin $4 \mathrm{~g} / \mathrm{dL}$, phosphorus of $6 \mathrm{mmol} / \mathrm{L}$ (reference value 0.97-1.45 mmol/L), and a pH of 7.0. The anion gap corrected 
for albumin will be $10 \mathrm{mEq} / \mathrm{l}$. When using equation 3 the SIG will be $6.78 \mathrm{mEq} / \mathrm{L}$ due to the high phosphorus level. The linear relationship of serum phosphorus and the ionic contribution in the SIG can be incorporated in the traditional AG formula (Figure 2). The SIG can thus be replaced by the following adjustment to the AG formula: Equation 5.

AG corrected for albumin and phosphorus $\left(\mathrm{AG}_{\mathrm{a}+\mathrm{p}}\right)=\left[\mathrm{Na}^{+}\right]-[\mathrm{Cl}$

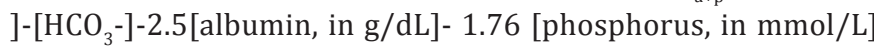
and as the median phosphorus level is about 1.2, the reference value will be about $-2+5 \mathrm{mEq} / \mathrm{L}$. A similar equation has been proposed by Kellum et al. [4].

\section{Conclusion}

In conclusion, the SIG and $\mathrm{AG}_{\mathrm{a}}$ are almost identical in a variety of physiological acid-base conditions. When phosphorus levels are elevated, one can use the less complex $A_{a+p}$ equation as an accurate representation of the SIG. To have a better understanding of the pathophysiology and to be more accurate, the anion gap, or perhaps a more logical term, "the ion gap" should be written as equation 5 to become almost identical to the SIG.

\section{Acknowledgment:}

We are indebted to Jan willem boldingh for making Figure 1.

\section{References}

1. Berend K, de Vries AP, Gans RO (2014) Physiological approach to assessment of acid-base disturbances. N Engl J Med 371(15): 14341445.

2. Gamble JL (1936) Extracellular fluid and its maintenance. N Engl J Med 250: $1150-1152$.

3. Kellum JA, Elbers (2009) PWG Stewart's textbook of acid-base, $\left(2^{\text {nd }}\right.$ edn) AcidBase.org, Amsterdam, UK.

4. Kellum JA (200) Determinants of blood pH in health and disease. Crit Care 4: 6-14.

5. Nguyen BV, Vincent JL, Hamm JB, Abalain JH, Carre JL, et al. (2009) The reproducibility of Stewart parameters for acid-base diagnosis using two central laboratory analyzers. Anesth Analg 109: 1517-1523.

\begin{tabular}{|l|}
\multicolumn{1}{c|}{ Your next Submission with Juniper Publishers } \\
will reach you the below assets \\
- Quality Editorial service \\
- Swift Peer Review \\
- Reprints availability \\
- E-prints Service \\
- Manuscript Podcast for convenient understanding \\
- Global attainment for your research \\
- Manuscript accessibility in different formats \\
( Pdf, E-pub, Full Text, Audio) \\
- Unceasing customer service \\
Track the below URL for one-step submission \\
https://juniperpublishers.com/online-submission.php \\
\end{tabular}

